\title{
PERUBAHAN SOSIAL EKONOMI MASYARAKAT DESA KEBOIRENG PASCA PEMBANGUNAN JALUR LINTAS SELATAN
}

(JLS)

\author{
Erika Vivian Nurchahyati \\ Universitas Negeri Surabaya \\ erika.18033@mhs.unesa.ac.id
}

$\underline{\text { Received : } 4 \text { May } 202 \text { | Reviewed: } 4 \text { June } 2021 \text { | Accepted: } 22 \text { June } 2021}$

\begin{abstract}
ABSTRAK
Pemerintah saat ini tengah gencar-gencarnya untuk melakukan pembangunan infrastruktur jalan. Pembangunan ini diharapkan untuk memudahkan mobilitas masyarakat sehingga juga dapat mengembangkan perekonomian masyarakat. salah satu proyek pemerintah dalam pembangunan infrastruktur adalah adanya pembangunan jalur lintas selatan (JLS). Jalur lintas selatan ini merupakan jalur yang menghubungkan seluruh wilayah yang berada di selatan Jawa Timur. Adanya pembangunan ini menyebabkan terjadinya perubahan pada kehidupan masyarakat terutama pada sosial dan ekonomi. Penelitian ini menggunakan metode penelitian kualitatif dengan menggunakan perspektif teori perubahan sosial Piotr Sztompka. Subyek penelitian adalah masyarakat yang bertempat tinggal disekitar jalur lintas selatan (JLS) dan adapun lokasi penelitian adalah di Desa Keboireng Kecamatan Besuki, Kabupaten Tulungagung.Hasil penelitian adalah setelah adanya pembukaan Jalur Lintas Selatan ditemukan sebuah tempat wisata yaitu Pantai Gemah dan Pantai Klatak. Adanya Jalur lintas Selatan ini menyebabkan berubahnya mata pencarian masyarakat setempat. Perubahan mata pencaharian tersebut adalah yang awalnya petani berubah menjadi pedagang di Pantai Gemah dan Pantai Klatak. Untuk perubahan sosialnya ditemui bahwa daerah yang dilalui Jalur Lintas Selatan menjadi berisik dan ditemui polusi udara karena banyaknya kendaraan yang menuju tempat wisata.
\end{abstract}

Kata Kunci: Perubahan Sosial Ekonomi, Pembangunan, Jalur Lintas Selatan

Korespondensi:

Universitas Negeri Surabaya

Jl. Lidah Wetan, Lidah Wetan, Kec. Lakarsantri, Kota

SBY, Jawa Timur 60213

E-mail: erika.18033@mhs.unesa.ac.id

JURNAL ILMIAH DINAMIKA SOSIAL 5 (1) 2021 | 1 


\begin{abstract}
The government is currently incessantly developing road infrastructure. This development is expected to facilitate community mobility so, that it can help the community's economy. One of these development is Jalur Lintas Selatan(JLS). This southern route is a route that connects all areas in the south of East Java. This development causes social changes in society, especially in social and economic terms. This study uses qualitative research methods using the perspective of Piotr Sztompka's theory of social change. The research subjects were people who lived around the JLS and the research location was in Keboireng Village, Besuki District, Tulungagung Regency. The results of the study were the existence of JLS has changed the livelihoods of the local community. The change in livelihood was that initially farmers turned into traders on Gemah Beach and Klatak Beach. For social change, it was found that the area traversed by the Southern Passage became noisy and air pollution was encountered due to the large number of vehicles heading for tourist attractions.
\end{abstract}

Keyword : socio-economic change, development, Jalur Lintas Selatan

\title{
PENDAHULUAN
}

Manusia dalam kehidupan pasti mengalami suatu perubahan. perubahan-perubahan ini tanpa disadari oleh manusia telah terjadi di berbagai hal yang ada di kehidupan terdekat masyarakat. Suatu perubahan ini dapat dirasakan secara disadari ataupun tidak disadari. Perubahan ini dapat disebabkan dari perubahan yang terjadi karena fisik atau non-fisik. Perubahan yang terjadi di masyarakat dapat terjadi karena adanya suatu faktor dari luar. Perubahan yang dari luar tersebut dapat dikategorikan menjadi tiga. Kategori tersebut adalah Directed Contact Change, Selective Contact Change, Immanent Change (Leibo, 1995). Directed Contact Change disini maksutnya perubahan tersebut dibawa sengaja oleh outsider sehingga terdapat suatu ide baru ataupun cara baru. Selective contact change di mana ide baru tersebut dibawa secara spontan atau secara tidak sadar dibawa kedalam sistem sosial di masyarakat. Immanent change merupakan sebuah perubahan sosial dimana perubahan tersebut berawal dari sebuah sistem tersebut ataupun perubahan tersebut ada inisiatif dari luar entah sedikit ataupun tidak sama sekali. Perubahan-perubahan yang terjadi di masyarakat lambat laun ataupu dapan terjadi dengan cepat akan di terima oleh masyarakat di daerah tersebut.

Perubahan sendiri dapat terjadi pada semua aspek yang ada di masyarakat. Aspek tersebut dapat berupa informasi dan komunikasi, hukum, politik, ilmu pengetahuan, agama, budaya bahkan ekonomi. Perubahan-perubahan tersebut dapat dilihat dengan jelas yaitu seperti 
kehidupan agraris tradisional menjadi masyarakat yang indutri modern, yang awalnya berazazkan kebersamaan menjadi individualisme. Perubahan-perubahan yang ada di masyarakat ini dapat terjadi karena adanya beberapa faktor. Faktor tersebut ikut serta dalam kontribusi adanya perubahan sosial di masyarakat. Adapun faktor-faktor tersebut adalah adanya interaksi dengan kebudayaan lain, pendidikan, rasa menghargai hasil karya orang lain dan keinginan untuk maju, toleransi, sistem terbuka dalam stratifikasi masyarakat, penduduk yang heterogen, adanya rasa tidak puas dalam bidang tertentu (Rosana, 2015). Adanya rasa kurang puas dan juga keinginan untuk memudahkan mobilitas masyarakat, maka dikembangkanlah infrastruktur di daerah tersebut.

Infrastruktur merupakan suatu kebutuhan dasar baik fisik ataupun sosial. Infrastruktur ini dibangun atau dikembangkan untuk memenuhi ataupun menunjang ekonomi masyarakat baik di sektor formal ataupun di sektor privat. Dalam Grigg (1988) membagi infrastrutur kedalam enam golongan besar yaitu kelompok jalan, kelompok produksi dan distribusi, kelompok pelayanan transportasi, kelompok bangunan serta fasilitas olahraga luar, kelompok air, kelompok manajemen limbah (Syukri, 2015). Kelompok jalan meliputi jalan biasa, jalan raya dan juga jembatan. Saat ini, Indonesia sedang gencar-gencarnya mengembangkan infrastruktur terutama dalam kategori Jalan.

Pembangunan jalan yang ada di Indonesia ini terjadi karena adanya faktor pendorong. Adapun faktor pendukung tersebut adalah dapat dilihat dari posisi geografik negara, kekayaan alam, penduduk, globalisasi ekonomi, kepercayaan kreditor luar negeri (Patarai, 2016). Posisi geoografi yang menunjang pembangunan dapat dilihat dari prioritas pembangunan ekonomi di negara tersebut, sumber daya alam, masalah yang terdapat di negara tersebut, dan akses sumber ekonomi yang dibutuhkan. Penduduk juga menjadi salah satu faktor pendorong. Hal ini dapat menjadi faktor pendorong apabila dapat memanfaatkan kualitas dari sumber daya manusia baik dari intelektual maupun fisik.

Progam pembangunan jalan di Indonesia ini dimaksudkan sebagai bentuk dari implementasi keadilan bagi seluruh masyarakat. Pembangunan infrastruktur jalan di Indonesia ini mulai gencar sejak pemerintahan Joko Widodo dan Jusuf Kalla. Pembangunan jalan sejak tahun 2014-2019 mencapai 4.119 km (Gewati, 2019). Pembangunan infrastruktur pada era pemerintahan Joko Widodo dan Jusuf Kalla ini meliputi pembangunan berupa jalan dan juga 
jembatan. Salah satu alasan memfokuskan pembangunan infrastruktur terumata pada jalan adalah untuk mengembangkan pertumbuhan ekonomi di Indonesia. Hal ini karena dengan dibangunnya infrastruktur jalan dapat memudahkan masyarakat untuk melakukan mobilitas. Mobilitas tersebut adalah baik mobilitas masyarakat itu sendiri ataupun mobilitas dari barang sehingga karena kemudahan akses tersebut menyebabkan terjangkaunya harga bahan pokok. Selain hal tersebut, pembangunan infrastruktur jalan dan juga jembatan ini juga berguna untuk menghubungkan satu daerah dengan daerah yang lainnya.

Pembangunan jalan di Indonesian memiliki tujuan. Tujuan dari pembangunan jalan adalah untuk mempermudah akses ke jalan utama. Pembangunan jalan ini juga memiliki kontribusi untuk memulihkan mata pencarihan. Jalan juga berfungsi sebagai alat untu mempermudah trasportasi darat. Fungsi lain dari jalan sendiri adalah menghubungkan satu wilayah dengan wilayah lainnya dimana hal tersebut berguna meningkatkan ekonomi, pendidikan dan juga memudahkan masyarakat mendapatkan suatu pelayanan masyarakat.

Pembangunan jalan membawa beberapa dampak positif di berbagai daerah yang mengalami pembangunan jalan. Sebagai contoh dampak positif yang dirasakan di pulau Sumatera adalah membantu masyarakat dalam segala jenis aktivitas sehari-hari (Ompusunggu, 2019). Hal positif tersebut adalah mempermudah untuk menjual hasil panen sehingga ekonomi masyarakat menjadi meningkat, mempersingkat jarak sehingga lebih efektif dan efesien, pembangunan lebih merata. Dampak positif dari pembangunan jalan yang dirasakan adalah dapat mempercepat waktu tempuh antar daerah, adanya kenaikan harga tanah disekitar tempat pembangunan jalan, mengurangi adanya kepadatan penduduk di suatu daerah (NSS, Suryawardana, \& Triyani, 2015).

Jawa Timur merupakan salah satu provinsi yang ada di Indonesia dimana seperti yang diketahui di Jawa banyak ditemui pembangunan untuk infrastruktur jalan. Pada tahun 2018 diketahui Jawa Timur memiliki panjang jalan nasional sebesar $2.361 \mathrm{~km}$ yang belum termasuk dengan jalan tol (Bappeda, 2018). Salah satu proyek besar yang ada di Indonesia adalah pembangunan jalan lintas pantai selatan Jawa Timur atau biasa dikenal dengan Jalur Lintas Selatan (JLS). Jalur ini merupakan salah satu pembangunan jalan besar di mana jalan ini bertujuan untuk menghubungkan seluruh wilayah yang ada di pantai selatan Pulau Jawa termasuk seluruh kabupaten yang ada di selatan Jawa Timur. Jalur Lintas Selatan yang ada di 
Jawa Timur ini melewati beberapa kabupaten. Kabupaten tersebut adalah dimulai dari Pacitan, Trenggalek, Tulungagung, Blitar, Malang, Lumajang yang kemudian berujung di Banyuwangi. Jalur Lintas Selatan (JLS) yang ada dibagian Jawa Timur ini direncana akan mencapai 680,13 Km (Bappeda, 2018). Rincian jalan tersebur adalah di Pacitan panjang jalan 87,44 Km, Trenggalek dengan panjang 78,35 Km, Tulungagung dengan panjang 54,97 Km, Blitar dengan panjang 66,85 Km, Malang dengan panjang 137,33 Km, Lumajang dengan panjang 65,60 Km, Jember dengan panjang 83,50 Km dan Banyuwangi dengan panjang 106,10 Km.

Dalam jurnal (Istiningsih, 2015) yang berjudul "Perubahan Sosial Ekonomi Masyarakat Pasca Pembangunan Jalan Tol Ungaran-Bawen" diketahui bahwa dengan adanya pembangunan jalan tol ini menyebabkan beberapa aspek di masyarakat Desa Kandangan, Kecamatan Bawen, Kabupaten Semarang mengalami perubahan. Dalam pembangunan tol ini masyarakat yang terelokasi mendapat uang ganti lahan di mana hal tersebut digunakan untuk meningkatkan perekonomian mereka. pembagunan tol ini membawa perubahan berupa kemajuan pada masyarakat Bawen dalam status sosial ekonomi, pendidikan, pendapatan, dan juga mata pencarian. Dalam skripsi (Fitri, 2018) berjudul "Dampak Pembangunan Infrastruktur Jalan Tol Terhadap Kondisi Sosial Ekonomi Masyarakat" masyarakat kecamatan Grati diketahui adanya pembanguna jalan ini menyebabkan berbagai dampak negatif. Dampak negatif tersebut diantaranya adalah lingkungan banyak yang rusak, hubungan sosial antar masyarakat menjadi renggang, adanya polusi suara dan sektor pertanian yang semakin berkurang. Di jurnal (Diartho, 2020) berjudul "Dampak dari Pembangunan Jalan Lintas Selatan (JLS) terhadap Kawasan Pesisir Pantai di Kabupaten Malang Selatan” dampak dari adanya JLS adalah memudahkan masuknya modal ataupun teknologi yang dibawa oleh pedatang karena kemudahan akses jalan tersebut. Kemudahan tersebut berdampak kepada terjadi perkembangan sumber daya manusia yang berkualitas. Perubahan-perubahan tersebut juga terjadi di kabupaten Tulungagung tepatnya di desa Keboireng. Desa Keboireng merupakan desa yang terkena dampak dari pembangunan jalur lintas selatan. Adanya jalur lintar selatan tersebut mempengaruhi sosial ekonomi masyarakat sekitar sehingga menyebabkan suatu perubahan di daerah sekitar Jalur Lintas Selatan (JLS).

\section{KAJIAN TEORI}

Dalam penelitian ini menggunakan teori perubahan sosial yang dikemukakan oleh Piotr Sztompka. Dalam teori perubahan sosial ini Sztompka berpendapat bahwa perubahan sosial 
yang ada di masyarakat terjadi karena adanya perubahan pada sistem sosial masyarakat (Suntari, 2017). Perubahan ini mempengaruhi pada unsur yang lain seperti ekonomi, sosial, politik dan keluarga. Perubahan ini akhirnya menyebabkan masyarakat ke dalam tatanan kehidupan baru. Menurut Sztompka perubahan sosial yang ada dimasyarakat terdapat tiga kriteria. Kriteria tersebut adalah studi tentang perbedaan, pengamatan pada sistem sosial, dimensi ruang yang erat kaitanya dengan sistem historis. Dalam hal ini perubahan sosial yang ada di masyarakat lama kelamaan membawa masyarakat kedalam keadaan yang lebih baik dan menguntungkan.

Piotr Sztompka berpendapat bahwa suatu perubahan dapat terjadi karena beberapa hal yaitu adanya perubahan komposisi, struktur, perubahan fungsi, batas, hubungan antarsubsistem, dan adanya perubahan lingkungan (Sztompka, 1993). Adanya perubahan komposisi ini dapat dilihat seperti adanya migrasi oleh suatu kelompok, dimana hal tersebut dapat mempengarui kebiasaan dan budaya di tempat tersebut. Perubahan struktur merupakan suatu perubahan di mana hal tersebut mempengaruhi struktur yang ada di masyarakat. perubahan fungsi dapat dikatakan seperti adanya stratifikasi atau diferensiasi pekerjaan di suatu daerah. Perubahan lingkungan yaitu suau perubahan karena terjadi perubahan di lingkungan itu sendiri.

\section{METODE PENELITIAN}

Dalam penelitian ini menggunakan metode penelitian kualitatif. Creswell (2008) mendefinisikan yang dimaksud metode penelitian kualitatif adalam suatu pendekatan atau penelurusan yang bertujuan untuk mengeksplorasi dan memahami suatu gejala sosial di imana dalam penelitian kualitatif ini lebih mengutamakan data yang sulit diukur dengan angkaangka dan keberadaannya nyata di masyarakat (Raco, 2010). Penelitian kualitatif digunakan untuk meneliti data-data yang tidak dapat diukur menggunakan angka-angka tetapi metode ini digunakan untuk meneliti dengan cara turun kelapangan dengan melakukan pendekatan ke masyarakat. Instrumen penrlitian pada penelitian kualitatif lebih ditekankan kepada manusia (Sadewo, 2016). Peneliti akan melakukan observasi langsung dengan melakukakn wawancara kepada informan yang terkait dengan judul penelitian yang akan diteliti.

Adapun waktu yang digunakan untuk melakukan penelitian adalah bulan FebruariApril. Dalam hal ini, peneliti akan melakukan wawancara untuk mendapatkan informasi secara mendalam. Adapun lokasi penelitian adalah tempat diadakannya penelitian ini. dalam 
penelitian ini lokasi yang akan digunakan adalah di Desa Keboireng, Kecamatan Besuki, Kabupaten Tulungagung. Alasan peneliti memilih lokasi ini dikarenakan lokasi yang dipilih dirasa tepat untuk mendapatkan data yang dicari. Untuk subyek penelitian adalah masyarakat yang bertempat tinggal di sekitar Jalur Lintas Selatan (JLS) Kabupaten Tulungagung.

Teknik pengumpulan data menggunakan wawancara dan observasi. Pengambilan dengan wawancara dilakukan dengan menannyai pertanyaan-pertanyaan kepada subyek penelitian, dengan atau tidaknya instrumen pertanyaan. Selain dengan wawancara peneliti juga menggunakan teknik pengumpulan data berupa observasi.

\section{PEMBAHASAN}

\section{Definisi Perubahan Sosial Ekonomi dan Masyarakat}

Suatu cara hidup yang dapat diterima dan menyebabkan suatu perubahan-perubahan baik perubahan tersebut secara geografis, material maupun dengan adanya suatu penemuan baru dan selama perubahan tersebut masih dapat diterima oleh masyarakat disebut suatu perubahan sosial. Adanya perubahan ini dikarenakan kehidupan masyarakat bersifat statis dan dinamis. Masyarakat bersifat statis merupakan suatu masyarakat yang mengalami suatu perubahan tetapi berjalan dengan lambat, sedangkan yang dimaksud masyarakat dinamis adalah suatu masyarakat yang mengalami perubahan secara cepat. Perubahan sosial ini terjadi karena mengacu kepada cara masyarakat untuk melakukan suatu perubahan guna memenuhi kebutuhan hidup. Perubahan sosial terjadi karena adanya ketidaksesuaian yang terjadi di unsurunsur sosial yang ada masyarakat, adanya ketidaksesuaian ini membuat masyarakat mengalami perubahan sehingga dalam bermasyarakat menghasilkan pola kehidupan yang baru. Adapun perubahan sosial ini mencangkup bermacam-macam aspek. Contohnya dapat berupa pelapisan sosial yang ada di masyarakat, lembaga kemasyarakatan, pola-pola perilaku sehari hari, kekuasaan dan wewenang di pemerintahan dan aspek-aspek lainnya.

Masyarakat merupakan suatu individu yang berkelompok dalam sebuah sistem yang antara satu individu dengan individu lainnya sebagian besar melakukan suatu interaksi. Hillery (1995) mendefinisikan masyarakat adalah sekolompok manusia yang mempunyai suatu aturan sosial(norma-norma) yang berlaku di kehidupan sehari-hari dan harus diataati oleh orang-orang . Dalam bahasa inggris masyarakat berarti "society". Society sendiri berasal dari bahasa latin yaitu societas (hubungan persahabatan dengan yang lain). Wilkinson (1972) mengartikan 
masyarakat sebagai suatu komunitas dimana antar individu saling tergantung satu sama lain,kelompok ini hidup bersama dalam suatu komunitas yang teratur. Masyarakat sendiri bertujuan untuk membangun suatu pengembangan peradaban sehingga suatu wilayah terjadi suatu kehidupan. Adanya interaksi di masyarakat ini membuat individu dengan individu lainnya mengalami keterbukaan karena hal ini dianggap oleh masyarakat dengan adanya keterbukaan dapat membuat terjadinya peningkatan-peningkatan situasi dan juga kemajuan kepentingan

\section{Jalur Lintas Selatan di Desa Keboireng, Kecamatan Besuki, Kabupaten Tulungagung}

Kabupaten Tulungagung merupakan salah satu kabupaten yang terkena pembangunan Jalur Lintas Selatan (JLS). Jalur Lintas Selatan ini merupakan pembangunan jalan yang merupakan salah satu proyek besar Indonesia. Adapun batas-batas wilayah dari kabupaten Tulungagung adalah di sebelah utara berbatasan dengan Kabupaten Kediri, sebelah selatan batas wilayahnya berbatasan langsung dengan Samudra Hindia, sebelah timur adalah Kabupaten Blitar dan di sebeleh barat adalah Kabupaten Trenggalek. Adanya pembangunan Jalur Lintas Selatan ini dimana dibangun untuk menghubungkan bagian selatan Jawa Timur menyebabkan pembangunan Jalur Lintas Selatan juga terjadi di Kabupaten Tulungagung. Jalur Lintas Selatan (JLS) ini melewati beberapa daerah yang ada di kabupaten Tulungagung, salah satunya adalah Desa Keboireng.

Desa Keboireng merupakan salah satu desa yang tertelatak di Kecamatan Besuki. Batas daerah dari Desa Keboireng sebelah Utara adalah desa Tanggul turus, sebelah timur adalah Desa Besuki, sebelah selatan adalah Samudera Hindia dan di sebelah barat adalah Desa Sedayugunung. Desa Keboireng yang terletak di bagian selatan ini dan berbatasan langsung dengan samudera Hindia menyebabkan Desa Keboireng menjadi salah satu desa yang dilewati Jalur Lintas Selatan. Sebelum dibangunnya Jalur Lintas Selatan daerah Desa Keboireng banyak dijumpai gunung di bagian selatan Desa Keboireng.

Jalur Lintas Selatan yang ada di Tulungagung ini mulai dibangun sekitar tahun 2015. Di awal tahun 2016 ini jalur lintas selatan sudah menarik banyak pengunjung. Hal ini karena keindahan dari jalur lintas selatan itu sendiri. Ketika berada di Jalur Lintas Selatan yang terdapat di Keboireng ini, dapat dilihat sekeliling sawah yang disusun rapi. Sawah-sawah tersebut mengikuti kontur tanah yang ada di daerah tersebut. Di Jalur lintas selatan tersebut 
juga membelah bukit dan juga lereng gunung. Hal ini menyebabkan bertambahnya keindahan dan pesona dari jalur lintas selatan tersebut.

Untuk melakukan pembangunan Jalur Lintas Selatan yang awalnya gunung maka daerah yang akan dijadikan jalan ini diratakan. Hal ini menyebabkan di samping kanan kiri jalan tetap terdapat gunung. Pada proses pembukaan jalan ini ternyata ditemukan dua pantai yang saling berdekatan. Pantai tersebut diberi nama Pantai Gemah dan Pantai Klatak. Pantai tersebut akhirnya digunakan masyarakat sebagai tempat wisata karena keindahan pantai tersebut. Antara Pantai Gemah dan Pantai Klatak dibatasi oleh gunung kecil. Adanya kedua pantai ini dimanfaatkan warga sekitar untuk mengembangkan potensi sekitar sehingga dapat membantu perekonomian masyarakat sekitar.

\section{Sosial Ekonomi Masyarakat Keboireng Sebelum Dan Setelah Terdapat Jalur Lintas Selatan (JLS)}

A. Sebelum Adanya Pembangunan Jalur Lintas Selatan

Desa Keboireng merupakan desa yang terletak di sebelah selatan Kecamatan Besuki. Daerah Desa Keboireng sebagian besar adalah pesawahan dan pegunungan. Karena daerah yang sebagian besar adalah pesawahan dan pegunungan ini menyebabkan masyarakat Desa Keboireng bermata pencaharian sebagai petani. Sebagia besar masyarakat bekerja di sawah dan juga ladang. Mereka biasanya menggarap sawah atau ladangnya sendiri, tetapi ada juga yang menggarap ladang atau sawah sewa. Adapula bagi mereka yang tidak mampu menyewa tanah dan tidak memiliki tanah mereka menjadi buruh tani.

Pertanian di Desa Keboireng terbagi menjadi dua bentuk. Hal tersebut yaitu ladang dan persawahan. Diketahui bahwa masyarakat Desa Keboireng yang bermata pencaharian sebagai petani sawah, panen setiap tiga kali selama satu tahun. Untuk petani ladang biasa mereka panen setiap satu sampai dua kali dalam setahun. Hal ini dikarenakan karena pertanian di daerah tersebut tergantung dengan musim. Di pertanian Desa Keboireng merupakan pertanian tadah hujan. Pertanian tadah hujan merupakan suatu pertanian di mana pengairan di pertanian tersebut mengandalkan curah hujan. Hal ini menyebabkan sawah di daerah tersebut ditanam secara bergantian. Di musim hujan sawah tersebut akan ditanam padi sedangkan di musim kemarau sawah akan ditanam 
tanaman palawija. Tetapi, tidak semua sawah pada musim kemarau ditanami tanaman palawija terkadang juga terdapat sawah yang pada musim kemarau tidak ditanami tanaman apapun.

Hasil dari sawah dan ladang digunakan masyarakat petani untuk memenuhi kebutuhan sehari-hari. Adapun beberapa hasil ladang yang biasa dihasilkan adalah ketela, pisang,kacang tanah. Untuk hasil dari sawah tergantung dengan musim nya. Pada musim hujan petani biasa menanam padi sedangkan pada musim kemarau sawah biasa ditanami tanaman palawija. Tanaman palawija tersebut seperti kedelai, jagung, timun, kacang panjang dan lain sebagainya. Beberapa hasil ladang tersebut di jual kepasar atau lewat tengkulak. Sedangkan untuk padi biasanya mereka menjual dalam bentuk beras. Tetapi, terdapat beberapa masyarakat yang beras tersebut dikonsumsi sendiri.

B. Setelah adanya pembangunan jalur lintas selatan

Seperti yang diketahui bahwa wilayah Desa Keboireng berada di dekat pantai selatan. Setelah adanya pembangunan jalur lintas selatan banyak ditemui pantai baru. Pantai tersebut pada awalnya belum diketahui oleh masyarakat. Tetapi, setelah adanya pembukaan jalan untuk jalur lintas selatan banyak ditemui surga tersembunyi di daerah lintasan jalur lintas selatan. Setelah adanya pembangunan tersebut ditemukan dua pantai yang dapat dimanfaatkan untuk potensi di desa tesebut. Pantai tersebut adalah Pantai Gemah dan juga Pantai Klatak. Selain pantai-pantai tersebut pemandangan di di jalan jalur lintas selatan juga tak kalah indah. Banyak pemandangan yang dapat dijadikan spot foto.

Indahnya pemandangan dan juga munculnya tempat wisata baru di Desa Keboireng ini menyebabkan perubahan pada masyarakat Desa Keboireng. Karena keindahan tempat tersebut membuat banyak wisatawan yang datang ke daerah tersebut. Hal ini dijadikan masyarakat untuk membuka usaha di sekitar jalur lintas selatan dan juga di sekitar pantai gemah dan pantai klatak. Untuk perizinannya sendiri hanya orang dari desa Keboireng yang diperbolehkan untuk berjualan di daerah tersebut. Hal ini karena pemerintah desa ingin mesejahterakan rakyatnya. Ini terbukti dengan banyaknya masyarakat Desa Keboireng yang berjualan. Mereka banyak berjualan seperti minuman dan juga makanan. 
Di sepanjang jalan jalur lintas selatan akan banyak dijumpai pedagang yang menjual berbagai menu makanan dan juga minuman. Mereka berjualan di pinggir jalan yang dekat dengan spot foto keindahan alam di jalur lintas selatan. Penempatan warung yang menghadap ke sawah dan juga pemandangan gunung menambah kesan. Masyarakat di bagian ini menjual minuman dingin dan terdapat juga warung makan angkringan yang menjual jajanan ringan. Di pantai Gemah dan Pantai Klatak masyarakat menjual berbagai olahan laut. Kebanyakan dari mereka menjual ikan bakar dan juga es degan. Terdapat pula masyarakat yang berjualan cinderamata. Cinderamata tersebut seperti berupa kaos, baju dan mainan. Ada juga masyarakat yang bekerja sebagai orang yang menjaga tempat untuk mandi dan juga toilet. terdapat pula masyarakat yang kini juga menjadi nelayan. Mereka memanfaatkan kekayaan alam yang ada di Pantai Gemah dan juga Pantai Klatak. Hasil dari tangkapan nelayan tersebut beberapa dijual mereka kepasar atau dijual di warung-warung untuk diolah menjadi ikan bakar yang nantinya dijual ke wisawatan di Pantai Gemah dan Pantai Klatak.

Masyarakat yang berjualan di pantai Gemah dan Pantai Klatak berpendapat bahwa setiap harinya penghasilan mereka lumayan banyak. Hal ini sangat berbeda ketika sebelum adanya pembangunan Jalur Lintas Selatan. Pantai Gemah dan Pantai Klatak selalu di banjiri oleh pengunjung. Hal ini hampir setiap hari terlepas pada hari libur atau tidak. Ramainya pengunjung ini juga membawa dampak positif bagi masyarakay Keboireng. Setelah adanya pembangunan ini tentunya menambah mata pencaharian mereka.

\section{Perubahan Sosial Ekonomi Masyarakat Keboireng Pasca Adanya Jalur Lintas Selatan}

Adanya pembangunan Jalur Lintas Selatan yang melewati Desa Keboireng ini membawa perubahan di sosial ekonomi masyarakatnya. Dapat dilihat yaitu dari sektor mata pencaharian terjadi perubahan. Sebelum adanya pembangunan jalur lintas selatan ini masyarakat banyak yang bermata pencaharian sebagai petani. Dimana dalam memenuhi kebutuhan sehari-hari yaitu bersumber dari hasil pertanian tersebut. Hasil pertanian tersebut dapat didapatkan dari ladang atau dari sawah yang dimilikinya. Bagi mereka yang memiliki atau mampu menyewa ladang atau sawah mereka menjadi buruh tani. Sehingga untuk memenuhi kebutuhan sehari-harinya didapatkan dari upah buruh tani tersebut. Setelah adanya pembangunan jalur lintas selatan perekonomian masyarakat dapat dibilang jauh meningkat 
dibandingkan sebelum adanya jalur lintas selatan. Hal ini dapat dilihat ketika terdapat jalur lintas selatan masyarakat menjadi pedagan dengan berjualan di pinggir jalan jalur lintas selatan. Selain itu mereka berdagang di pantai Gemah dan Pantai Klatak.

Menurut Piotr Sztompka adanya suatu perubahan sosial terjadi karean adanya perubahan sistem sosial dimasyarakat. Hal ini dapat dilihat dari masyarakat desa Keboireng yang awalnya hanya mengandalkan hasil pertanian kini dapat mencari keuntungan dari berjualan di Pantai yang ditemukan dari pembukaan Jalur Lintas Selatan. Masyarakat kini dapat memanfaatkan hasil pertanian untuk makan sehari-hari sedangakan laba dari hasil dagang mereka dapat digunakan untuk menabung. Hal ini tentunya membawa perubahan kedalam bentuk positif. Selain itu mereka yang bekerja sebagai buruh tani dengan upah rendah dapat juga berjualan di pantai Gemah dan Pantai Klatak. Dengan banyaknya wisawatawan yang datang membuat jualan dari masyarakat yang berdagang di sekitar daerah tersebut menjadi laku keras.

Adanya perubahan sosial dan ekonomi dimasyarakat Keboireng ini juga terjadi karena faktor lingkungan. Hal ini sesuai dengan pendapat Sztompka dimana perubahan sosial di masyarakat dapat terjadi karena faktor dari perubahan lingkungan di daerah tersebut. Pada awalnya lingkungan di daerah Desa Keboireng kebanyakan adalah pertanian sehingga mereka kebanyakan bekerja di sektor pertanian. hasil tani yang bergantung dari musim menyebabkan kurang mampu memenuhi kebutuhan dari masyarakat tersebut. Adanya pembangunan Jalur Lintas Selatan ini menyebabkan terjadi perubahan pada lingkungan di desa Keboireng. Ditemukannya beragam pesona alam menyebabkan desa Keboireng dilirik oleh wisatawan. Masyarakat yang memanfaatkan keadaan tersebut akhirnya memunculkan ide baru untuk berdagang di sekitar jalan dan di Pantai tersebut. Dahulu ibu-ibu yang tidak mempunyai pekerjaan dirumah, setelah adanya obyek wisata tersebut akhirnya dapat membantu perekonomian keluarga dengan cara berjualan. Hal ini membuktikan bahwa adanya perubahan di lingkungan mempengaruhi perubahan di masyarakat pula.

\section{KESIMPULAN}

Adanya pembangunan Jalur Lintas Selatan membawa suatu perubahan bagi masyarakat di Desa Keboireng. Sebelum adanya Jalur Lintas Selatan, untuk memenuhi kebutuhan ekonominya mereka bertumpu kepada hasil pertanian saja. Setelah adanya Jalur lintas selatan 
ini menyebabkan banyak tereksposnya keindahan alam di daerah tersebut, salah satunya adalah ditemukannya pantai Gemah dan Pantai Klatak. Adanya hal tersebut dimanfaatkan masyarakat untuk meningkatkan perekonomian mereka sehingga untuk itu mereka berjualan di daerah tersebut. Dengan adanya hal tersebut tentunya pembangunan yang ada di masyarakat menyebabkan adanya perubahaan dimana perubahan tersebut dapat meningkatkan perekonomian masyarakat.

\section{Kutipan Buku :}

\section{DAFTAR PUSTAKA}

Leibo, J. (1995). Sosiologi Pedesaan Mencari Suatu Strategi Pembangunan Masyarakat Desa Berparadigma Ganda. Yogyakarta: Andi Offset.

Patarai, M. I. (2016). PERENCANAAN PEMBANGUNAN DAERAH. Makassar: De La Macca.

Raco, J. (2010). Metode penelitian kualitatif: jenis, karakteristik dan keunggulannya (A. L, Ed.).

Sadewo, F. S. (2016). Meneliti Itu Mudah (M. Legowo, Ed.). Surabaya: Unesa University Press.

Suntari, S. (2017). MODUL PENGEMBANGAN KEPROFESIAN BERKELANJUTAN Sosiologi. Jakarta Pusat: Direktorat Jenderal Guru dan Tenaga Kependidikan Kementerian Pendidikan dan Kebudayaan.

Sztompka, P. (1993). Sosiologi Perubahan Sosial. Jakarta: Prenada.

\section{Kutipan Artikel Jurnal :}

Diartho, H. C. (2020). Dampak dari Pembangunan Jalan Lintas Selatan (JLS) terhadap Kawasan Pesisir Pantai di Kabupaten Malang Selatan. Ecoplan, 3(2), 119-129.

Fitri, N. N. (2018). Dampak Pembangunan Infrastruktur JalanTol Terhadap Kondisi Sosial Ekonomu Masyarakat. Universitas Jember.

Istiningsih, A. (2015). PERUBAHAN SOSIAL EKONOMI MASYARAKAT PASCA 
PEMBANGUNAN JALAN TOL UNGARAN-BAWEN (Studi Kasus di Desa Kandangan Kecamatan Bawen Kabupaten Semarang). Jurnal Forum Ilmu Sosial, 42(2), 127-139.

NSS, R. L. P., Suryawardana, E., \& Triyani, D. (2015). Analisis Dampak Pembangunan Infrastruktur Jalan Terhadap Pertumbuhan Usaha Ekonomi Rakyat Di Kota Semarang. Jurnal Dinamika Sosial Budaya, 17(1), 82. https://doi.org/10.26623/jdsb.v17i1.505

Ompusunggu, V. M. (2019). DAMPAK PEMBANGUNAN INFRASTRUKTUR JALAN TERHADAP PERTUMBUHAN EKONOMI MASYARAKAT DI DESA SEMANGAT GUNUNG, KABUPATEN KARO, SUMATERA UTARA. Jurnal Pendidikan Ekonomi, $3(2), 18-26$.

Rosana, E. (2015). Modernisasi dalam Perspektif Perubahan Sosial. Al-Adyan Jurnal Studi Lintas Agama, 10(1), 67-82.

Syukri, M. R. (2015). Pemetaan sebaran infrastruktur jalan dan telekomunikasi kota gorontalo. RADIAL - JuRnal PerADaban SaIns, RekayAsa Dan TeknoLogi, 3(1), 1-6.

\section{Kutipan Website :}

Bappeda. (2018). Pembangunan Infrastruktur Di Jawa Timur. In Bappeda Jawa Timur. Retrieved from https://www.google.co.id/search?safe=strict\&ei=rJekW9P7L42o9QPh57G4Ag\&q=pem bangunan+infrastruktur+di+jawa+timur\&oq=pembangunan+infrastruktur+di+j\&gs_l=ps $\mathrm{y}-$

ab.1.1.0j0i203k1j0j0i203k114j0i22i30k113.1327231.1335730.0.1337731.30.30.0.0.0.0.1 $57.2850 .17 \mathrm{j} 11.28 .0$

Gewati, M. (2019). Alasan Pemerintah Jokowi-JK Fokus Bangun Infrastruktur. Retrieved March 17, 2021, from Kompas.com website: https://money.kompas.com/read/2019/03/26/084500826/alasan-pemerintah-jokowi-jkfokus-bangun-infrastruktur?page=all 